\title{
Influence of Breed, Sex and Anatomical \\ Location on Lipid and Fatty Acid \\ Composition of Bovine Subcutaneous Fat
}

\author{
Toyonobu Yoshimura and Kiyoshi Namikawa \\ Department of Animal Science, College of Agriculture, \\ Kyoto University, Kyoto-shi, 606
}

(Received July 22, 1982)

\begin{abstract}
Thirty-one animals including Japanese Black ( 9 steers), Holstein ( 8 steers and 2 heifers) and Japanese Black $\times$ Holstein $\left(F_{1}\right)(6$ steers and 6 heifers $)$ were used to determine the lipid and fatty acid composition of subcutaneous fat at a constant slaughter weight. Subcutaneous fat samples for the lipid analysis were taken from the shoulder, loin, rump, brisket and flank regions. Total lipid contents extracted from subcutaneous fat were not significantly affected by breed, sex and location, although Japanese Black had a tendency to have somewhat more total lipid content than Holstein. Percentages of TG and PL were significantly affected by sex and anatomical location. Heifers had a higher percentage of TG and a lower percentage of PL. Flank subcutaneous fat had the highest percentage of $\mathrm{TG}$ and the lowest percentage of PL. The effects of breed, sex and location on the fatty acid composition of TG, PL and FFA classes were significant with some exceptions and similar tendencies were observed in the fatty acid composition of these classes. The principal features were as follows; (1) Japanese Black were higher in $\mathrm{C} 18: 1$ and TUSF contents, and $\mathrm{C18} / \mathrm{C} 16$ ratio than Holstein, and the reverse was true for saturated fatty acids, i. e., C14:0, C16:0 and C18:0 fatty acids, while $F_{1}$ animals had intermediate values between their parental breeds for these fatty acids; (2) heifers had more unsaturated fatty acids in TG and PL classes than steers; (3) flank subcutaneous fat was less abundant in unsaturated fatty acids than other locations. From the above mentioned results, it was suggested that the fatty acid composition of lipid classes varied with the factors and particularly the breed effect was most remarkable.
\end{abstract}

Jpn. J. Zootech. Sci., 54 (2): 97-105: 1983

In beef cattle, as well as other meat animals, fat is one of the major components of the carcass and not only its quantitative distribution and partition, but also its qualitative characteristics play an important role in determining carcass quality. Therefore, the quantitative and qualitative variation of carcass fat is related to the economy and efficiency of beef production. On the other hand, its quantity and quality vary among individuals derived from different breeds, sexes, ages and feeding conditions and among fat depots ${ }^{1.2}$. In spite of the general recognition that there are marked differences in the propensity of fattening, the carcass quality between Japanese Black and Holstein, as well as between heifers and steers, little information is available as to the qualitative aspects of the beef carcass fat as concerned to the breed and sex.

In many reports ${ }^{3-17}$, the quality of carcass fat was understood as its physical and chemical property or its constitutional fatty acids of total lipids. Though triglycerides normally comprise over $90 \%$ of the total lipids in adipose tissue ${ }^{18}$, phospholipids and 
other lipids, which may have important roles in flavor and in the keeping quality of meat, are still included. Therefore, it is necessary to clarify the lipid and fatty acid composition of the adipose tissue systematically. In addition, in most of these reports with regard to subcutaneous, intermuscular and visceral depot fat, only one or two samples collected from a given depots were considered as representatives of such a depot or whole body, and the effect of the location within a fat depot on these composition has not been clarified sufficiently.

The present study, as a part of the fundamental research on improving beef carcass characteristics, was conducted to determine the lipid and fatty acid composition of bovine subcutaneous fat as related to breed, sex and anatomical location at a constant slaughter weight.

\section{Materials and Methods}

Animals. Thirty-one animals were used in this study, including Japanese Black (9 steers), Holstein (8 sterrs and 2 heifers) and Japanese Black $\times$ Holstein $\left(F_{1}\right)(6$ steers and 6 heifers). They were full-fed on ordinary fattening rations from $6 \sim 8$ months of age after weaning, except for the 3 Holstein steers which were limited-fed during the initial 6 month period and thereafter full fed. Most of animals were slaughtered at the end point of $550 \mathrm{~kg}$ live weight, but the 6 Holstein steers were slaughtered at $600 \mathrm{~kg}$. The slaughter age of animals ranged from 454 to 754 days.

Sample Collection. Subcutaneous fat samples were collected from five locations on the left side of each carcass at the time of dissection after a 48 hour chilling period. The shoulder (over the 5 th thoracic vertebra), loin (over the 2 nd lumber vertebra), rump (pin bone edge), brisket (over the last sternebra) and flank (hind flank) comprised the locations. Samples were placed in polyethylene bags and immediately frozen and stored $\left(-20^{\circ} \mathrm{C}\right)$ until required for chemical analysis.

Lipid Analysis. Frozen subcutaneous fat was crushed with a mortar and pestle. Lipids were extracted from the crushed fat samples with chloroform and methanol solvent $\left.(2: 1, \mathrm{v} / \mathrm{v})^{19}\right)$. Each portion of the lipid extract was subsequently used for determination of total lipid contents, lipid composition and the fatty acid composition of three lipid classes.

Total lipid contents ( $\mathrm{mg} / \mathrm{g}$ wet tissue) were determined gravimetrically ${ }^{20)}$.

In order to determine lipid composition, the lipids were separated into classes by thin-layer chromatography (TLC) and then charred with $70 \%$ sulfuric acid saturated with potassium dicromate ${ }^{21}$. Quantitative estimation of each lipid class was performed densitometrically.

The fatty acid composition of triglycerides (TG), free fatty acids (FFA) and phospholipids (PL) was determined by gas-liquid chromatography (GLC) followed by preparative TLC. That is, the lipids were separated by preparative TLC and visualized according to the procedure by $\mathrm{KATES}^{22)}$. Each lipid class was immediately scraped into an incubation tube and then methyl esterification was performed by the $\mathrm{HCl}$ methanol method as described by YaMaKawA ${ }^{23)}$. 
The fatty acid metyl esters were separated on a dual column gas chromatograph, equipped with a flame ionization detector and nitrogen was used as the carrier gas at a flow rate of $60 \mathrm{ml} / \mathrm{min}$. A $3.0 \mathrm{~mm} \mathrm{I}$. D. $\times 3.0 \mathrm{~m}$ glass column was packed with $15 \%$ diethylene succinate coated onto $80 / 100$ mesh chromosorb $W$ (acid washed). Column temperature program was linearly conducted by $3^{\circ} \mathrm{C} / \mathrm{min}$ from $170^{\circ} \mathrm{C}$ to $205^{\circ} \mathrm{C}$, while detectors were maintained at $220^{\circ} \mathrm{C}$. Fatty acid peak areas were quantified with an electric integrator.

Statistical Analysis. Data were analyzed by least-squares procedure ${ }^{24}$ using the computer program, LSML 76 ${ }^{25)}$. The model included four fixed effects (i. e., breed, sex, anatomical location and nutrition level); the two-way interaction between breed and location; and pooled and within-breed partial regression on slaughter weight (average $523 \mathrm{~kg}$ ). Duncan's new multiple range test was used to determine which differences between means was significant ${ }^{26)}$.

\section{Results}

Seven lipid classes, i. e., TG, PL, FFA, cholesterol (CH), diglycerides (DG), monoglycerides (MG) and cholesterol esters (CE) were identified on the thin-layer chromatogram. However, because of the trace amounts of $\mathrm{MG}$ and $\mathrm{CE}$, these classes were not quantified. In addition, relative minor classes of $\mathrm{CH}$ and $\mathrm{DG}$ were not included in the statistical analysis (Table 1).

Table 1. Least-squares means and standard errors for total lipid contents and lipid composition ${ }^{11,21}$

\begin{tabular}{|c|c|c|c|c|}
\hline \multirow[b]{2}{*}{ Effect } & \multirow{2}{*}{$\begin{array}{c}\text { Total lipids } \\
\text { (mg/g } \\
\text { tissue) }\end{array}$} & \multicolumn{3}{|c|}{ Lipid class } \\
\hline & & $\begin{array}{l}\text { T G } \\
(\%)\end{array}$ & $\underset{(\%)}{\mathrm{PL}}$ & $\underset{(\%)}{F A^{3)}}$ \\
\hline \multicolumn{5}{|l|}{ Breed } \\
\hline Japanese Black & $897.6(13.2)$ & $91.4(0.6)$ & $2.9(0.3)$ & $3.0(0.3)$ \\
\hline $\mathrm{B} \times \mathrm{H}\left(\mathrm{F}_{1}\right)$ & $889.3(13.5)$ & $90.8(0.6)$ & $2.9(0.3)$ & $2.9(0.3)$ \\
\hline Holstein & $870.9(6.1)$ & $92.0(0.3)$ & $3.0(0.1)$ & $2.7(0.1)$ \\
\hline Sex & & $* *$ & $*$ & \\
\hline Steer & $880.2(7.0)$ & $90.7(0.3)^{b}$ & $3.2(0.1)^{\mathrm{a}}$ & $2.9(0.2)$ \\
\hline Heifer & $883.6(12.4)$ & $92.1(0.5)^{\mathrm{a}}$ & $2.7(0.2)^{b}$ & $2.8(0.2)$ \\
\hline Location & & $* *$ & $* *$ & \\
\hline Shoulder & $886.1(10.2)$ & $91.4(0.4)^{b c}$ & $3.0(0.2)^{\mathrm{a}}$ & $2.8(0.2)$ \\
\hline Loin & 883.8 & $90.9^{c}$ & $3.1^{\mathrm{a}}$ & 3.1 \\
\hline Rump & 891.9 & $91.7^{\mathrm{ab}}$ & $2.9^{a b}$ & 2.7 \\
\hline Brisket & 876.4 & $90.9^{b c}$ & $3.2^{\mathrm{a}}$ & 3.0 \\
\hline Flank & 891.5 & $92.2^{2}$ & $2.6^{\mathrm{b}}$ & 2.7 \\
\hline
\end{tabular}

1) The relative amounts of lipid classes are expressed as relative weight percentages of TG, PL, FFA, CH and DG. 2) The figures within parentheses show the standard errors. 3) The abbreviation used are as follows: TG, triglycerides; PL, phospholipids; FFA, free fatty acids. $* P<0.05$. ** $\mathrm{P}<0.01$. $\mathrm{a}, \mathrm{b}, \mathrm{c}$ : Within a main effect, means in the same column with no common superscripts differ significantly $(P<0.05)$. 
Twelve fatty acids were identified on the gas chromatogram of the fatty acid methyl esters of TG and FFA. Three more fatty acids were usually contained in the PL class. Therefore, the fatty acid composition of each class was expressed as weight percentages of these fatty acid methyl esters. The statistical analyses were carried out for the major fatty acids of each class (Table 2, 3 and 4).

Although the results of analysis of variance are not shown here, the nutritional level effect and the linear effect were significant for several lipid classes and their constitutional fatty acids. On the other hand, breed $\times$ location interaction was not significant for any of them.

\section{Total Lipid Contents and Lipid Composition.}

The least-squares means of total lipid contents and lipid composition by breed, sex and location are shown in Table 1.

The total lipid contents were not significantly affected by any of the factors. Japanese Black, however, had a tendency to have somewhat more total lipid content than Holstein. In the analysis of lipid classes, percentages of TG and PL were significantly affected by sex and anatomical location (Table 1). The least-squares means showed that the percentage of TG was lower $(\mathrm{P}<0.01)$ and that of $\mathrm{PL}$ was higher

Table 2. Least-squares means and standard errors for the fatty acid composition ${ }^{11,2)}$ of triglycerides

\begin{tabular}{|c|c|c|c|c|c|c|c|c|}
\hline \multirow{2}{*}{ Effect } & \multicolumn{8}{|c|}{ Fatty acid ${ }^{3)}$} \\
\hline & $\underset{(\%)}{C 14: 0}$ & $\begin{array}{c}\mathrm{C} 16: 0 \\
(\%)\end{array}$ & $\begin{array}{c}\text { C } 16: 1 \\
(\%)\end{array}$ & $\begin{array}{c}\text { C 18:0 } \\
(\%)\end{array}$ & $\underset{(\%)}{\mathrm{C} 18: 1}$ & $\begin{array}{c}\text { C 18:2 } \\
(\%)\end{array}$ & $\underset{(\%)}{\text { TUSF }^{41}}$ & $\mathrm{C} 18 / \mathrm{C} 16^{5}$ \\
\hline Breed & $* *$ & $* *$ & & $* *$ & $* *$ & $* *$ & $* *$ & $* *$ \\
\hline Japanese Black & $\begin{array}{c}2.3^{b} \\
(0.2)\end{array}$ & $\begin{array}{l}21.0^{\mathbf{b}} \\
(0.7)\end{array}$ & $\begin{array}{c}6.9 \\
(0.5)\end{array}$ & $\begin{array}{c}8.2^{b} \\
(0.7)\end{array}$ & $\begin{array}{l}53.6^{2} \\
(0.9)\end{array}$ & $\begin{array}{r}2.2^{c} \\
(0.3)\end{array}$ & $\begin{array}{l}65.1^{\mathrm{a}} \\
(1.1)\end{array}$ & $\begin{array}{r}2.2^{\mathrm{a}} \\
(0.1)\end{array}$ \\
\hline $\mathrm{B} \times \mathrm{H} \quad\left(\mathrm{F}_{1}\right)$ & $\begin{array}{r}2.5^{b} \\
(0.2)\end{array}$ & $\begin{array}{l}23.1^{\mathrm{a}} \\
(0.7)\end{array}$ & $\begin{array}{c}7.1 \\
(0.5)\end{array}$ & $\begin{array}{c}8.8^{b} \\
(0.8)\end{array}$ & $\begin{array}{l}49.4^{b} \\
(1.0)\end{array}$ & $\begin{array}{r}3.4^{\mathrm{a}} \\
(0.3)\end{array}$ & $\begin{array}{l}62.2^{\mathrm{b}} \\
(1.1)\end{array}$ & $\begin{array}{l}1.9^{0} \\
(0.1)\end{array}$ \\
\hline Holstein & $\begin{array}{l}3.0^{\mathrm{a}} \\
(0.1)\end{array}$ & $\begin{array}{l}24.3^{a} \\
(0.3)\end{array}$ & $\begin{array}{c}6.9 \\
(0.2)\end{array}$ & $\begin{array}{l}10.3^{\mathrm{a}} \\
(0.3)\end{array}$ & $\begin{array}{l}46.9^{\mathrm{c}} \\
(0.4)\end{array}$ & $\begin{array}{c}2.8^{b} \\
(0.5)\end{array}$ & $\begin{array}{l}58.9^{c} \\
(0.5)\end{array}$ & $\begin{array}{l}1.9 b \\
(0.01)\end{array}$ \\
\hline Sex & $* *$ & $* *$ & & & $* *$ & & $* *$ & \\
\hline Steer & $\begin{array}{r}2.8^{\mathrm{a}} \\
(0.1)\end{array}$ & $\begin{array}{l}23.6^{\mathrm{a}} \\
(0.4)\end{array}$ & $\begin{array}{c}6.8 \\
(0.2)\end{array}$ & $\begin{array}{c}9.4 \\
(0.4)\end{array}$ & $\begin{array}{l}48.8^{b} \\
(0.5)\end{array}$ & $\begin{array}{c}2.9 \\
(0.1)\end{array}$ & $\begin{array}{l}60.9^{b} \\
(0.6)\end{array}$ & $\begin{array}{l}1.9 \\
(0.04)\end{array}$ \\
\hline Heifer & $\begin{array}{r}2.3^{b} \\
(0.2)\end{array}$ & $\begin{array}{l}22.0^{b} \\
(0.6)\end{array}$ & $\begin{array}{c}7.1 \\
(0.4)\end{array}$ & $\begin{array}{c}8.8 \\
(0.7)\end{array}$ & $\begin{array}{l}51.1^{\mathrm{A}} \\
(0.9)\end{array}$ & $\begin{array}{c}2.7 \\
(0.2)\end{array}$ & $\begin{array}{r}63.2^{\mathrm{a}} \\
(1.1)\end{array}$ & $\begin{array}{c}2.0 \\
(0.1)\end{array}$ \\
\hline Location & * & $* *$ & $* *$ & $* *$ & $* *$ & & $* *$ & $* *$ \\
\hline Shoulder & $\begin{array}{l}2.6^{\mathrm{ab}} \\
(0.1)\end{array}$ & $\begin{array}{l}23.8^{\mathrm{a}} \\
(0.5)\end{array}$ & $\begin{array}{r}7.2^{\mathrm{a}} \\
(0.4)\end{array}$ & $\begin{array}{r}8.2^{\mathrm{a}} \\
(0.6)\end{array}$ & $\begin{array}{l}49.6^{\mathrm{ab}} \\
(0.7)\end{array}$ & $\begin{array}{c}2.8 \\
(0.2)\end{array}$ & $\begin{array}{l}62.2^{\mathrm{a}} \\
(0.9)\end{array}$ & $\begin{array}{r}1.9^{b} \\
(0.1)\end{array}$ \\
\hline Loin & 2. $5^{b}$ & $23.5^{\mathrm{ab}}$ & $7.2^{\mathrm{a}}$ & $8.2^{\mathrm{a}}$ & $50.0^{a b}$ & 2.7 & $62.4^{2}$ & 1. $9^{b}$ \\
\hline Rump & $2.5^{\mathrm{b}}$ & $22.1^{\mathrm{cd}}$ & $7.3^{\mathrm{a}}$ & $8.7^{\mathrm{a}}$ & $50.5^{2}$ & 2.9 & $63.1^{\mathrm{a}}$ & 2. $0^{\mathrm{a}}$ \\
\hline Brisket & $2.5^{b}$ & $21.9^{d}$ & $7.2^{\mathrm{a}}$ & $8.8^{\mathrm{a}}$ & $50.8^{a}$ & 2.8 & $63.3^{\mathrm{a}}$ & $2.0^{\mathrm{a}}$ \\
\hline Flank & $2.8^{a}$ & 22. $7^{b c}$ & $5.8^{b}$ & $11.7^{b}$ & 48. $8^{b}$ & 2.7 & $59.3^{\mathrm{b}}$ & 2. $1^{\mathrm{a}}$ \\
\hline
\end{tabular}

1) Fatty acids are expressed as the relative weight percentages of 12 fatty acid methyl esters. 2) The figures within parentheses show the standard errors. 3) Number of carbon atoms: number of double bonds. 4) Total unsaturated fatty acids. 5) $(\mathrm{C} 18: 0+\mathrm{C} 18: 1) /(\mathrm{C} 16: 0+\mathrm{C} 16: 1)$ ratio. $* \mathrm{P}<0.05, * * \mathrm{P}<0.01$. a, b, c, d: Within a main effect, means in the same column with no common superscripts differ significantly $(\mathrm{P}<0.05)$. 
Fatty Acids of Bovine Subcutaneous Fat

Table 3. Least-squares means and standard errors for the fatty acid composition ${ }^{1,21}$ of free fatty acids

\begin{tabular}{|c|c|c|c|c|c|c|c|c|}
\hline \multirow{2}{*}{ Effect } & \multicolumn{8}{|c|}{ Fatty acid ${ }^{3)}$} \\
\hline & $\begin{array}{c}C 14: 0 \\
(\%)\end{array}$ & $\begin{array}{c}\text { C 16:0 } \\
(\%)\end{array}$ & $\underset{(\%)}{C 16: 1}$ & $\begin{array}{c}\mathrm{C} 18: 0 \\
(\%)\end{array}$ & $\begin{array}{c}\text { C } 18: 1 \\
(\%)\end{array}$ & $\begin{array}{c}\mathrm{C} 18: 2 \\
(\%)\end{array}$ & $\begin{array}{c}\text { TUSF }^{4)} \\
(\%)\end{array}$ & $\mathrm{C} 18 / \mathrm{C}^{16^{5}}$ \\
\hline Breed & * & $* *$ & & $* *$ & $* *$ & & $* *$ & $* *$ \\
\hline Japanese Black & $\begin{array}{c}1.9^{b} \\
(0.3)\end{array}$ & $\begin{array}{l}11.0^{c} \\
(1.1)\end{array}$ & $\begin{array}{l}10.4 \\
(0.8)\end{array}$ & $\begin{array}{l}5.4^{\mathrm{b}} \\
(0.7)\end{array}$ & $\begin{array}{l}60.6^{\mathrm{a}} \\
(1.5)\end{array}$ & $\begin{array}{c}4.0 \\
(0.5)\end{array}$ & $\begin{array}{r}77.9^{a} \\
(1.6)\end{array}$ & $\begin{array}{r}3.0^{a} \\
(0.2)\end{array}$ \\
\hline $\mathrm{B} \times \mathrm{H} \quad\left(\mathrm{F}_{1}\right)$ & $\begin{array}{r}1.8^{b} \\
(0.3)\end{array}$ & $\begin{array}{l}13.4^{\mathrm{b}} \\
(1.1)\end{array}$ & $\begin{array}{c}9.4 \\
(0.8)\end{array}$ & $\begin{array}{c}7.0^{\mathrm{a}} \\
(0.7)\end{array}$ & $\begin{array}{l}56.8^{0} \\
(1.6)\end{array}$ & $\begin{array}{c}5.2 \\
(0.5)\end{array}$ & $\begin{array}{l}73.9^{b} \\
(1.7)\end{array}$ & $\begin{array}{r}2.8^{\mathrm{a}} \\
(0.2)\end{array}$ \\
\hline Holstein & $\begin{array}{c}2.3^{2} \\
(0.1)\end{array}$ & $\begin{array}{l}16.3^{\mathrm{a}} \\
(0.5)\end{array}$ & $\begin{array}{c}9.1 \\
(0.4)\end{array}$ & $\begin{array}{r}7.6^{3} \\
(0.3)\end{array}$ & $\begin{array}{l}53.4^{\mathrm{c}} \\
(0.7)\end{array}$ & $\begin{array}{c}4.6 \\
(0.2)\end{array}$ & $\begin{array}{l}70.0^{c} \\
(0.8)\end{array}$ & $\begin{array}{r}2.5^{6} \\
(0.1)\end{array}$ \\
\hline \multicolumn{9}{|l|}{ Sex } \\
\hline Steer & $\begin{array}{c}2.2 \\
(0.1)\end{array}$ & $\begin{array}{l}14.0 \\
(0.6)\end{array}$ & $\begin{array}{c}9.7 \\
(0.4)\end{array}$ & $\begin{array}{c}6.4 \\
(0.3)\end{array}$ & $\begin{array}{l}57.1 \\
(0.8)\end{array}$ & $\begin{array}{c}4.3 \\
(0.3)\end{array}$ & $\begin{array}{l}73.8 \\
(0.9)\end{array}$ & $\begin{array}{c}2.7 \\
(0.1)\end{array}$ \\
\hline Heifer & $\begin{array}{c}1.8 \\
(0.2)\end{array}$ & $\begin{array}{l}13.1 \\
(1.0)\end{array}$ & $\begin{array}{c}9.6 \\
(0.7)\end{array}$ & $\begin{array}{c}6.9 \\
(0.6)\end{array}$ & $\begin{array}{l}56.8 \\
(1.4)\end{array}$ & $\begin{array}{c}4.9 \\
(0.4)\end{array}$ & $\begin{array}{l}74.0 \\
(1.5)\end{array}$ & $\begin{array}{c}2.8 \\
(0.2)\end{array}$ \\
\hline Location & & $*$ & $* *$ & $* *$ & & & $* *$ & $*$ \\
\hline Shoulder & $\begin{array}{c}2.0 \\
(0.2)\end{array}$ & $\begin{array}{l}14.8^{\mathrm{a}} \\
(0.7)\end{array}$ & $\begin{array}{r}9.7^{\mathrm{a}} \\
(0.6)\end{array}$ & $\begin{array}{l}6.4^{\mathrm{b}} \\
(0.5)\end{array}$ & $\begin{array}{l}55.9 \\
(1.2)\end{array}$ & $\begin{array}{c}4.6 \\
(0.4)\end{array}$ & $\begin{array}{l}73.1^{b c} \\
(1.3)\end{array}$ & $\begin{array}{r}2.6^{\mathrm{b}} \\
(0.1)\end{array}$ \\
\hline Loin & 2.0 & $13.7^{\mathrm{abc}}$ & $10.0^{a}$ & $6.1^{\mathrm{b}}$ & 57.1 & 4.5 & $74.3^{\mathrm{ab}}$ & $2.7^{\mathrm{ab}}$ \\
\hline Rump & 1.9 & 12. $9^{\mathrm{abc}}$ & $10.1^{a}$ & $6.3^{b}$ & 57.4 & 4. 7 & 74. $9^{a b}$ & $2.8^{\mathrm{ab}}$ \\
\hline Brisket & 1.9 & $12.6^{\mathrm{c}}$ & $10.2^{\mathrm{a}}$ & $6.1^{\mathrm{b}}$ & 57.8 & 4.0 & $75.5^{\mathrm{a}}$ & $2.8^{a b}$ \\
\hline Flank & 2.1 & 13. $9^{a b}$ & 8. $2^{b}$ & 8. $3^{\mathrm{a}}$ & 56.4 & 4.6 & $71.7^{\mathrm{c}}$ & $2.9^{\mathrm{a}}$ \\
\hline
\end{tabular}

1) Fatty acids are expressed as the relative weight percentages of 12 fatty acid methyl esters.

2) The figures within parentheses show the standard errors. 3) Number of carbon atoms: number of double bonds. 4) Total unsaturated fatty acids. 5) $(\mathrm{C} 18: 0+\mathrm{C} 18: 1) /(\mathrm{C} 16: 0+\mathrm{C} 16: 1)$ ratio. $* \mathrm{P}<0.05, * * \mathrm{P}<0.01$. a, b, $\mathrm{c}$ : Within a main effect, means in the same column with no common superscripts differ significantly $(\mathrm{P}<0.05)$.

$(\mathrm{P}<0.05)$ in steers than in heifers. Among locations, the flank and rump subcutaneous fat had the highest percentages of $\mathrm{TG}$ and the lowest percentages of $\mathrm{PL}(\mathrm{P}<$ 0.01 ). In contrast with these locations, the reverse was true for the loin and brisket fat.

Fatty Acid Composition of TG, FFA and PL.

The least-squares means of the percentages of the major fatty acids of TG, FFA and PL are shown in Table 2, 3 and 4, respectively. The least-squares means of total unsaturated fatty acids (TUSF) and (C18:0 $+\mathrm{C} 18: 1) /(\mathrm{C} 16: 0+\mathrm{C} 16: 1)$ ratio (C18) C16 ratio) are also shown in these tables. The latter value may reveal the degree of fatty acid chain-elongation whose activity has been demonstrated in bovine ${ }^{27}$, with the assumption that $\mathrm{C16:0}$ is the normal product of fatty acid synthesis de novo.

In the TG class, all fatty acids and indices represented in Table 2 were more or less affected by breed, sex and/or location. The breed effect, however, was most prominent among three factors. Particularly, percentages of C18:1 and C16:0 fatty acids which were most abundantly contained in bovine subcutaneous fat were most remarkably affected by breed. That is to say, Japanese Black had the highest percentage of C18:1 $(\mathrm{P}<0.01)$, while Holstein had the lowest. The reverse was true for saturated 
Table 4. Least-squares means and standard errors for the fatty acid composition ${ }^{1,2)}$ of phospholipids

\begin{tabular}{|c|c|c|c|c|c|c|c|c|c|}
\hline \multirow[b]{2}{*}{ Effect } & \multicolumn{9}{|c|}{ Fatty acid ${ }^{3)}$} \\
\hline & $\begin{array}{c}\mathrm{C} 14: 0 \\
(\%)\end{array}$ & $\begin{array}{c}\mathrm{C} 16: 0 \\
(\%)\end{array}$ & $\begin{array}{c}\mathrm{C} 16: 1 \\
(\%)\end{array}$ & $\begin{array}{c}\text { C 18:0 } \\
(\%)\end{array}$ & $\begin{array}{c}\mathrm{C} 18: 1 \\
(\%)\end{array}$ & $\begin{array}{c}\text { C 18:2 } \\
(\%)\end{array}$ & $\begin{array}{c}\mathrm{C} 20: 4 \\
(\%)\end{array}$ & $\begin{array}{c}\left.\text { TUSF }^{4}\right) \\
(\%)\end{array}$ & $\left.\mathrm{C} 18 / \mathrm{C} 16^{5}\right)$ \\
\hline Breed & & $* *$ & $*$ & $* *$ & $* *$ & $* *$ & & $* *$ & $* *$ \\
\hline Japanese Black & $\begin{array}{l}1.2 \\
(0.3)\end{array}$ & $\begin{array}{l}13.2^{b} \\
(1.1)\end{array}$ & $\begin{array}{l}8.0^{\mathrm{a}} \\
(0.7)\end{array}$ & $\begin{array}{r}9.2^{b} \\
(1.0)\end{array}$ & $\begin{array}{l}51.0^{\mathrm{a}} \\
(1.9)\end{array}$ & $\begin{array}{r}3.9^{c} \\
(0.6)\end{array}$ & $\begin{array}{l}3.0 \\
(1.0)\end{array}$ & $\begin{array}{l}72.4^{a} \\
(1.6)\end{array}$ & $\begin{array}{r}4.0^{\mathrm{a}} \\
(0.2)\end{array}$ \\
\hline $\mathrm{B} \times \mathrm{H} \quad\left(\mathrm{F}_{1}\right)$ & $\begin{array}{c}1.1 \\
(0.3)\end{array}$ & $\begin{array}{l}15.1^{\mathrm{b}} \\
(1.2)\end{array}$ & $\begin{array}{l}7.1^{a b} \\
(0.7)\end{array}$ & $\begin{array}{l}11.2^{\mathrm{b}} \\
(1.0)\end{array}$ & $\begin{array}{l}41.7^{b} \\
(2.0)\end{array}$ & $\begin{array}{r}6.7^{\mathrm{a}} \\
(0.6)\end{array}$ & $\begin{array}{c}4.0 \\
(1.0)\end{array}$ & $\begin{array}{l}66.5^{b} \\
(1.6)\end{array}$ & $\begin{array}{r}3.3^{b} \\
(0.2)\end{array}$ \\
\hline Holstein & $\begin{array}{l}1.5 \\
(0.1)\end{array}$ & $\begin{array}{l}17.2^{\mathrm{a}} \\
(0.5)\end{array}$ & $\begin{array}{l}6.2^{b} \\
(0.3)\end{array}$ & $\begin{array}{l}13.1^{\mathrm{a}} \\
(0.5)\end{array}$ & $\begin{array}{l}39.9^{b} \\
(0.9)\end{array}$ & $\begin{array}{r}4.9^{b} \\
(0.3)\end{array}$ & $\begin{array}{c}5.0 \\
(0.5)\end{array}$ & $\begin{array}{l}62.0^{c} \\
(0.7)\end{array}$ & $\begin{array}{l}3.0^{b} \\
(0.1)\end{array}$ \\
\hline Sex & & $* *$ & & & & * & & $* *$ & $* *$ \\
\hline Steer & $\begin{array}{c}1.2 \\
(0.2)\end{array}$ & $\begin{array}{l}17.0^{2} \\
(0.6)\end{array}$ & $\begin{array}{c}7.0 \\
(0.4)\end{array}$ & $\begin{array}{l}11.7 \\
(0.5)\end{array}$ & $\begin{array}{l}43.9 \\
(1.0)\end{array}$ & $\begin{array}{r}4.6^{b} \\
(0.3)\end{array}$ & $\begin{array}{l}3.5 \\
(0.5)\end{array}$ & $\begin{array}{l}64.8^{b} \\
(0.8)\end{array}$ & $\begin{array}{r}3.2^{b} \\
(0.1)\end{array}$ \\
\hline Heifer & $\begin{array}{c}1.3 \\
(0.3)\end{array}$ & $\begin{array}{l}13.4^{b} \\
(1.1)\end{array}$ & $\begin{array}{c}7.1 \\
(0.7)\end{array}$ & $\begin{array}{l}10.6 \\
(0.9)\end{array}$ & $\begin{array}{l}44.6 \\
(1.8)\end{array}$ & $\begin{array}{c}5.7^{\mathrm{a}} \\
(0.5)\end{array}$ & $\begin{array}{c}4.5 \\
(0.9)\end{array}$ & $\begin{array}{l}69.2^{a} \\
(1.5)\end{array}$ & $\begin{array}{l}3.7^{\mathrm{a}} \\
(0.2)\end{array}$ \\
\hline Location & & & & $* *$ & $* *$ & & & & \\
\hline Shoulder & $\begin{array}{c}1.3 \\
(0.2)\end{array}$ & $\begin{array}{l}16.1 \\
(0.9)\end{array}$ & $\begin{array}{r}7.5^{a} \\
(0.6)\end{array}$ & $\begin{array}{l}10.3^{b} \\
(0.8)\end{array}$ & $\begin{array}{l}45.0 \\
(1.5)\end{array}$ & $\begin{array}{c}4.9 \\
(0.4)\end{array}$ & $\begin{array}{c}3.4 \\
(0.7)\end{array}$ & $\begin{array}{l}67.2 \\
(1.2)\end{array}$ & $\begin{array}{c}3.3 \\
(0.2)\end{array}$ \\
\hline Loin & 1.2 & 15.7 & $7.2^{\mathrm{a}}$ & $10.6^{b}$ & 44.3 & 5.0 & 4.3 & 67.1 & 3.3 \\
\hline Rump & 1.2 & 14.8 & $7.3^{\mathrm{a}}$ & $11.0^{6}$ & 44.7 & 5.2 & 3.8 & 67.4 & 3.5 \\
\hline Brisket & 1.2 & 14.3 & $7.6^{\mathrm{a}}$ & $11.1^{\mathrm{b}}$ & 44.3 & 5.3 & 3.9 & 68.0 & 3.6 \\
\hline Flank & 1.4 & 15.1 & $5.9^{b}$ & $12.8^{a}$ & 42.8 & 5.2 & 4.5 & 65.3 & 3.5 \\
\hline
\end{tabular}

1) Fatty acids are expressed as the relative weight percentages of 15 fatty acid methyl esters.

2) The figures within parentheses show the standard errors. 3) Number of carbon atoms: number of double bonds. 4) Total unsaturated fatty acids. 5) $(\mathrm{C} 18: 0+\mathrm{C} 18: 1) /(\mathrm{C} 16: 0+\mathrm{C} 16: 1)$ ratio. $* \mathrm{P}<0.05, * * \mathrm{P}<0.01$. a, b, c: Within a main effect, means in the same column with no common superscripts differ significantly $(P<0.05)$.

fatty acids, i. e., C14:0, C16:0 and C18:0 acids. For these fatty acids, $\mathrm{F}_{1}$ animals had a tendency to have intermediate values between their parental breeds. Only C18:2 fatty acid was contained in $F_{1}$ at a higher level than both breeds. These differences indicated that Japanese Black had the highest percentage of TUSF, while Holstein had the lowest and $F_{1}$ had an intermediate value. Since Japanese Black had the lowest percentage of $\mathrm{C} 16: 0$ and the breed difference was smaller in C18:0 than in C18:1 (i. e., $2 \%$ vs $7 \%$ ), Japanese Black had a higher $\mathrm{C} 18 / \mathrm{C} 16$ ratio than others. Between sex, steers had a lower percentage of $\mathrm{C} 18: 1$ and higher percentages of $\mathrm{C} 14: 0$ and $\mathrm{C} 16: 0$ than heifers $(\mathrm{P}<0.01)$. Thus steers had a lower percentage of TUSF than heifers $(P<0.05)$. The fatty acid composition of $T G$ class from the flank region differed from other subcutaneous locations. The flank subcutaneous fat contained the highest percentages of $\mathrm{C} 16: 0(\mathrm{P}<0.01)$ and $\mathrm{C18:0}(\mathrm{P}<0.05)$, resulting in the lowest percentage of TUSF. C18/C16 ratio was higher in the flank, brisket and rump than in other locations.

The least-squares means of the fatty acid composition of FFA and PL classes are shown in Tabble 3 and 4, respectively. Once again the breed effect was most 
prominent in these classes, as well as that of TG. The similar tendencies to that of TG observed in the fatty acid composition of FFA and PL classes, though the percentages of a given fatty acid of each class differed from each other (for example, C18:1 fatty acid contained in the Japanese Black subcutaneous fat was 53.6, 60.6 and $51.0 \%$ with regard to TG, FFA and PL classes, respectively). C20:4 fatty acid of the PL classes, which is one of the specific polyunsaturated fatty acids localized in the cell membrane was not significantly affected by any of factors.

\section{Discussion}

In preceding reports ${ }^{28.29}$, breed and sex differences for total lipid contents were recognized in bovine subcutaneous fat obtained from animals which were not wellfattened. The increment of total lipid contents, however, occured primarily at an early stage of growth and fattening in the $\mathrm{pig}^{30}$, sheep ${ }^{31)}$ and cattle ${ }^{811}$. Therefore, in well-fattened animals, the lipid contents per unit tissue reached the maximum level and were consequently less influenced by breed, sex and location. In fact, LovEDAY et al. ${ }^{32}$ found that in their comprehensive crossbreeding experiment, there were no breed differences in total lipid contents of bovine adipose tissue.

A little information is available as to the lipid composition of bovine subcutaneous fat. It was reported that no lipid classes were significantly affected by breed and sex $^{33.34)}$. Though some differences were observed in our results, the lipid composition may not be so modified by breed, sex and location, as well as the total lipid contents.

The fatty acid composition of TG, FFA and PL classes were affected by breed, sex and location, and then the similar tendencies were observed in the fatty acid composition of these classes. These results corresponded with many reports in which the fatty acid composition of total lipids obtained from bovine subcutaneous fat was affected by breed ${ }^{12,13,15,16)}$, sex $^{5,66}$ and location ${ }^{8,35)}$. Since adipose tissue was the major site of fatty acid synthesis in ruminants ${ }^{218}$ ) and the principal fatty acids synthesized in bovine adipose tissue were $\mathrm{C} 16: 0, \mathrm{C} 18: 0$ and $\mathrm{C} 18: 1^{27}$, the differences in the fatty acid composition may be due to the endogenous fatty acid synthetic mechanism including desaturation and chain-elongation. Several research workers, however, reported that in general the fatter and older the animals of a given breed, the more mono-unsaturated their depot fat becomes ${ }^{5,7,13,14,16,17)}$. Therefore, it is possible that the breed and sex effects were confounded with age effect, since the heifers were older than the steers and the Japanese Black were also older than the Holstein, when fattening cattle were compared at a constant weight. Thus, in addition to our present study, it is necessary to compare animals slaughtered at a constant age or various stages of fattening in order to obtain exact information about the breed and sex differences.

As described in our foregoing results and discussion, the fatty acids obtained from each class was made up of primary lipids which varied with breed, sex and location. It was recognized in general that firmness of carcass fat was influenced by the fatty acid composition and Tsuchry et al. ${ }^{4}$ reported that fat color was correlated with melting points and iodine numbers. On the other hand, lipids, especially fatty acids, 
were one of the important precursors of various flavor compounds, such as aldehydes, primary alcohols, $r$-lactones etc ${ }^{36}$. In the studies on meat flavor, it was revealed that the basal flavor of meat was common to meat animals, while the differences in the fatty acid composition resulted in those of carbonyl compounds after pyrolysis ${ }^{37.33)}$. Recently, SELKE et al. $^{39-41)}$ have reported that volatile components from heated model triglycerides, including tristearin, triolein and trilinolein were different from each other. From their results, it is possible that the fatty acid composition was one of the major factors associated with meat flavor. In fact, WesterLIng and HedrICK ${ }^{17}$ ) revealed that $\mathrm{C} 18: 1$ fatty acid was positively correlated with meat flavor. It is suggested from our results and their reports that among the lipids analyzed in this study, the fatty acids were the most probable compounds which are related to meat appearance and palatability. In particular, the remarkable breed difference in C18:1 which was the most abundant fatty acid in bovine subcutaneous fat is of interest in connection with the general recognition that there are differences in fat color and quality, and meat palatability between Japanese Black and Holstein.

\section{Acknowledgements}

This work was supported in part by two Scientific Research Grants from the Ministry of Education, Science and Culture (Grant No. 086032 and 286057).

We are greatful to Dr. T. Furushima (Kobe Univ.), Dr. M. Zenbayashi (the Livestock Farm, Kyoto Univ.), Mr. K. Mrtani (the University Farm, Hiroshima Univ.) and their staffs for their cooperation in feeding and management of experimental animals.

\section{References}

1) Berg, R. T. and R. M. Butrerfield, New Concepts of Cattle Growth. 143-175. Sydoney Univ. Press. Sydoney. 1976.

2) Leat, W. M. F., in Meat Animals. (Lister, D., D. N. Rhodes, V. R. Fowler and M. F. Fuller, eds.) 177-193. Plenum Press. New York and London. 1976.

3) Callow, E. H. and S. R. Searle, J. Agric. Sci., 48: 61-69. 1956.

4) Tsuchiya, H., K. Takahashi, K. Asano, T. Nishino and I. Katayosz, Bull. Chugoku Agric. Exp. Sta., B11: 65-73. 1963.

5) Waldman, R. C., G. G. Suess and V. H. Brungardt, J. Anim. Sci., 27: 632-635. 1968.

6) Terrell, R. N., G. G. Suess and R. W. Bray, J. Anim. Sci., 28: 449-453. 1969.

7) Link, B. A., R. W. Bray, R. G. Cassens and R. G. Kauffman, J. Anim. Sci., 30: 722-725. 1970.

8) Rumsey, T. S., R. R. Oltjen, K. P. Bovard and B. M. Priode, J. Anim. Sci., 35: 1069-1075. 1972.

9) Dryden, F. D., J. A. Marcello, W. C. Figroid and W. H. Hale, J. Anim. Sci., 36: 19-24. 1973.

10) Skelley, G. C., W. C. Stanford and R. L. Edwards, J. Anim. Sci., 36: 576-580. 1973.

11) Clemens, E., V. Arthaud, R. Mandigo and W. Woods, J.Anim. Sci., 37: 1326-1331. 1973.

12) Gillis, A.T. and N.A. M. Eskin, J. Food Sci., 38: 408-411. 1973.

13) Hecker, A. L., D. A. Cramer and D. F. Hougham, J. Food Sci., 40: 144-149. 1975.

14) Leat, W. M. F., J. Agric. Sci., Camb., 85: 551-558. 1975.

15) Pyle, C. A., J. J. Bass, D. M. Duganzich and E. Pyne, J. Agric. Sci., Camb., 89: 571-574. 1977.

16) Lent, W. M. F., J. Agric. Sci., Camb., 89: 575-582. 1977.

17) Westerling, D. B. and H. B. Hedrick, J. Anim. Sci., 48: 1343-1348. 1979.

18) Allen, C. E., D. C. Beitz, D. A. Cramer and R. G. Kauffman, Biology of Fat in Meat Animals. North Central Regional Res. Pub. No. 234. 1976.

19) Folch, J., M. Lees and G. H. Solane Staneley, J. Biol. Chem., 226: 497-509. 1957.

20) Kawade, M., in Chemical Analysis for Clinic. vol. 3. (Niwa, M., M. Kitamura and M. Saito, eds.) 1st ed. 25-39. Tokyo-Kagaku-Dojin. Tokyo. 1966. (in Japanese) 
Fatty Acids of Bovine Subcutaneous Fat

21) Kanno, T. and T. Hrrabayashi, Jpn. J. Clin. Pathol., 17: 567-570. 1969.

22) Kates, M., Laboratory Techniques in Biochemistry and Molecular Biology-Techniques of Lipidology. (Work, T.S. and E. Work, eds.) North-Holland Pub. Comp. Amsterdam. 1972.: translated in Japanese by Yamakawa, T., K. Saito and A. Hayashi, Tokyo-Kagaku-Dojin. ! Tokyo. 1975.

23) Yamanaka, T., in Lecture on Biochemical Experiments. vol. 3. Chemistry of Lipids. 197-209. Tokyo-Kagaku-Dojin. Tokyo. 1974. (in Japanese)

24) HaRvey, W. R., Least-squares Analysis of Data with Unequal Subclass Numbers. A.R.S., 20-8. U. S. D. A. 1960.

25) HARVEY, W.R., User's Guide for LSML76-Mixed Model Least-squares and Maximum Liklihood Computer Program. Mimeo. Ohio State Univ. Columbus. 1977.

26) Duncan, D. B., Biometrics, 11: 1-42. 1955.

27) Pothoven, M. A., D. C. Beit $Z$ and A. Zimmerd I, J. Nutr., 103: 468-475. 1973.

28) Callow, E. H., J. Agric. Sci., 58: 295-307. 1962.

29) BRĂNnÄNG, E., Lantbrukshögsk. Ann., 32: 329-419. 1966.

30) Anderson, D. B., R. G. Kauffman and L. L. Kastenscmidt, J. Lipid Res., 13: 593-599. 1972.

31) JAN, D., Studies on Relationship of Fat Accumulation and Lipogenesis in Bovine and Ovine Adipose Tissue. $\mathrm{Ph}$. D. thesis, Kyoto Univ., Kyoto. 1977. (in Japanese)

32) Loveday, H. D., M. E. Dikeman, M. C. Hunt and A. D. Dayton, J. Anim. Sci, 47: 606-614. 1978.

33) Thrall, B. E. and D. A. Cramer, J. Food Sci., 36: 194-198. 1971.

34) Hecker, A. L., D. A. Cramer, D. K. Beede and R. W. Hamil ton, J. Food Sci, 40: 140-143. 1975.

35) Garcia, P. T., J. J. Parodi and L. Marangunich, Meat Sci, 3: 169-177, 1979.

36) Litman, I. and S. Numrych, in Lipids as a Source of Flavor. (Supran, N. K. ed.) 1-17. Am. Chem. Soc., Washington, D. C., 1978.

37) Hornstein, I. and P. F. Crowe, J. Agric. Food Sci., 8: 494-498. 1960.

38) Hornstein, I., P. F. Crowe and W. L. Sul zbacher, Nature, 199: 1252-1254. 1963.

39) Selke, E., W. K. Rohwedder and H. J. Dutron, J. Am. Oil Chem. Soc., 52: 232-235. 1975.

40) Serke, E., W. K. Rohwedder and H. J. Dutton, J. Am. Oil Chem. Soc., 54: 62-67. 1977.

41) Selke, E., W. K. Rohwedder and H. J. Dutron, J. Am. Oil Chem. Soc., 57: 25-30. 1980.

\title{
牛の皮下脂肪組織中脂質および脂肪酸組成に 対する品種，性および蓄積部位の影響
}

\author{
吉村豊信・並河 澄 \\ 京都大学農学部, 京都市 606
}

之殺時体重を一定にした場合の，牛の皮下脂肪組織中 脂質および脂肪酸組成に対する品種，性および部位の影 響を明らかにする目的で，以下のように分析を実施し た. 材料は, 黒毛和種 (含: 9頭)，ホルスタイン種（古： 8頭，早：2 頭）および黑毛和種×ホルスタイン種 $\left(\mathrm{F}_{1}\right)$ (吉: 6 頭, $9: 6$ 頭) 計 31 頭の肥育牛の枝肉から, 解体

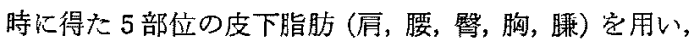
総脂質含量，脂質組成㧍よびトリグリ七リド(TG)，遊離 脂肪酸 (FFA)，リン脂質 (PL) の各画分の脂肪酸組成を 求めた。総脂質含量は，黑毛和種で高い傾向が認好 たが，品種を台むいずれの原因に関しても有意性注認る られなかった．脂質組成に関しては，TG\%と PL\%にお いて，性㧍よび部位の効果が有意であった，性間では， 末経産牛が去勢牛上りも TG\%が高く, PL\%が低く, 一 方部位間では，下膁部皮下脂肪が最も TG に富み， PL
が少ない傾向にあった．各画分の脂肪酸組成に対する各 要因の効果は，いくつかの例外を除いて有意であり，し かも，品種，性，部位の各要因ごとに妨た脂肪酸組成の 差異は、いずれの画分においても類似した傾向を示した。 その主要な特徵は以下の通りであった。(1)品種間では, 黒毛和種がホルスタイン種よりもC18:1, TUSF(総不飽 和脂肪酸割合）飞富み， $\mathrm{C} 18 / \mathrm{C} 16$ 比艻高く，これに対し て, C14:0，C16:0，C18:0などの飽和脂肪酸沙少かっ た。一方， $F_{1}$ は両品種の中間値学上る傾向に西った。(2) 末経産牛江去勢牛上りむ，TG，PL画分に打いて不飽和 脂肪酸に富えでいた。（3) 部位間では，下摄部で不飽和脂 肪酸が最も少なかった。以上の結果，一定と殺時体重べ 一スでは，脂質画分中の脂肪酸組成が各要因の影響索受 けやすく，とくに品種の効果が顕著であることが示唆さ れた。 日畜会報，54 (2)：97-105, 1983 